Journal of Zhejiang University-SCIENCE A (Applied Physics \& Engineering)

ISSN 1673-565X (Print); ISSN 1862-1775 (Online)

www.zju.edu.cn/jzus; www.springerlink.com

E-mail: jzus@zju.edu.cn

\title{
Report:
}

\section{Recent research on the track-subgrade of high-speed railways}

\author{
Ren-peng $\mathrm{CHEN}^{\dagger}$, Jin-miao CHEN, \\ Han-lin WANG \\ (Department of Civil Engineering, Zhejiang University, Hangzhou \\ 310058, China) \\ †E-mail: chenrp@zju.edu.cn
}

doi: $10.1631 /$ jzus.A1400342

\section{Background}

In recent years, the rapid development of high-speed railways in China has surprised the world with the so-called "China speed". The total mileage of high-speed railway will reach $1.6 \times 10^{4} \mathrm{~km}$ by 2020 . As a result, "High-speed Railway Diplomacy" has become a national strategy. In the world, many countries are making their high-speed railway plans. The safety and comfort of high-speed trains raises the strict demands on the performance of the tracksubgrade system during the service life over 100 years, for example, strict post-construction settlement at millimeter level, appropriate dynamic stiffness, and long-term durability. Under extreme climatic conditions such as heavy rainfall, persistent drought, and extreme low or high temperatures, long-term dynamic loading on the track-subgrade will cause many engineering problems, including excessive settlement, mud pumping, cracks in the slab, large voids under the slab, erosion of the reinforced concrete structure. Those engineering problems have been found in many operational high-speed railways. The research into the problems is still insufficient.

\footnotetext{
* Project supported by the National Natural Science Foundation of China (Nos. 51225804, U1234204, 51178418, and 51222803), and the Research Fund by China Railway Corporation (No. 2014G006) (iD) ORCID: Ren-peng CHEN, http://orcid.org/0000-0001-6968-4955 (C) Zhejiang University and Springer-Verlag Berlin Heidelberg 2014
}

\section{Dynamic response of track-subgrade}

The research on the dynamic response of train-track-subgrade has made many achievements. Zhai et al. (2009; 2013a; 2013b) has established a robust 35-degree-of-freedom vehicle-track coupled dynamics model. Dynamic responses of the carriages can be analyzed by this model in the case of carriages passing over curved tracks. Much research on the dynamic response of the subgrade has been conducted using analytical methods (Metrikine, 2004), 3D dynamic finite element method (Hall, 2003), 2.5D finite element method (Bian et al., 2008), field monitoring (Mishra et al., 2012; Verbraken et al., 2012; Cui et al., 2014), and model tests (Chen et al., 2013; 2014a; 2014b). Those studies have shown that the track-subgrade vibration is significantly associated with the train speed. There exists a critical train speed close to the Rayleigh wave velocity of the tracksubgrade (Bian et al., 2008). When the train speed is slower than the critical speed the vibration level increases almost linearly with the train speed. When the train speed equals the critical speed, the resonance of the track-subgrade causes a great increase in the vibration level. In practice, due to the high quality of fill material used in the subgrade construction, the critical speed is always higher than the train speed. Hence, the resonance can hardly be observed through field monitoring and model tests.

The dynamic stress on the subgrade surface is an important design load which is used to design the subgrade and the soil improvement measures. There are many factors that influence the dynamic stress on the subgrade, including carriage type, train speed, track type, and environmental factors. From field measurement, it can be found that the dynamic stress on the subgrade surface ranges from $15-20 \mathrm{kPa}$ for ballastless track, and 50-100 kPa for ballast track. In the Chinese Code for Design of High Speed Railway 
TB 10621 (MRC, 2009), the dynamic load magnification factor (DLF) for the subgrade is 3.0 for a train speed of $300 \mathrm{~km} / \mathrm{h}$, and 2.5 for a train speed of 250 $\mathrm{km} / \mathrm{h}$. In the German Railway Standard Rail 836 (2008), for a train speed of $300 \mathrm{~km} / \mathrm{h}$, the DLF of the slab is 1.7 to 2.1 , and 1.24 to 1.5 for the subgrade. The influence of environmental factors, such as the unevenness of the rail caused by the settlement of the subgrade, the degradation of the subgrade stiffness on the dynamic stress needs further study. In-situ measurement or full-scale model tests can be used to study the distribution of dynamic stress in the subgrade.

It is regarded that the influence depth of the dynamic stress on the performance of the subgrade is only $3 \mathrm{~m}$ for ballastless track. Beneath $3 \mathrm{~m}$ the dynamic stress is so small that it can be neglected. The distribution of the dynamic stress in the subgrade with the depth can be derived from Boussinesq's solution, though the shape of the subgrade and the ground soil is not an exact elastic half-space. Most of the research on the dynamic stress was conducted without the consideration of soil improvement piles. In China, the soft or loose soils under the embankment will be improved with piles. The method for calculating the dynamic stress in the subgrade with Boussinesq's solution should be further verified for a piled embankment. It is found from a full-scale model test for a low embankment improved with piles that the soil arching (Fig. 1) changes the distribution of dynamic stress in the subgrade (Chen et al., 2014c): the dynamic stress above the pile caps is enhanced greatly; on the contrary, the dynamic stress above the soil between the caps decreases greatly (Fig. 2). The large number of cycles of dynamic loading on the pile cap will cause the accumulative settlement of the pile. It is found that when $(\mathrm{SLR}+\mathrm{CLR})<0.5$ (SLR: static loading ratio; CLR: cyclic loading ratio), there is no accumulative settlement of the pile in silt soils (Chen et al., 2011). The study on the accumulative settlement of the pile under a large number of cycles of dynamic loading should be made in future studies.

Future research will focus on the ground and structure vibration due to the train passing, and protection methods will be studied for vibration sensitive structures. Studies on certain kinds of railway sections, such as the inhomogeneous soil profile in longitudinal and lateral directions, and transition sections, should be proposed.

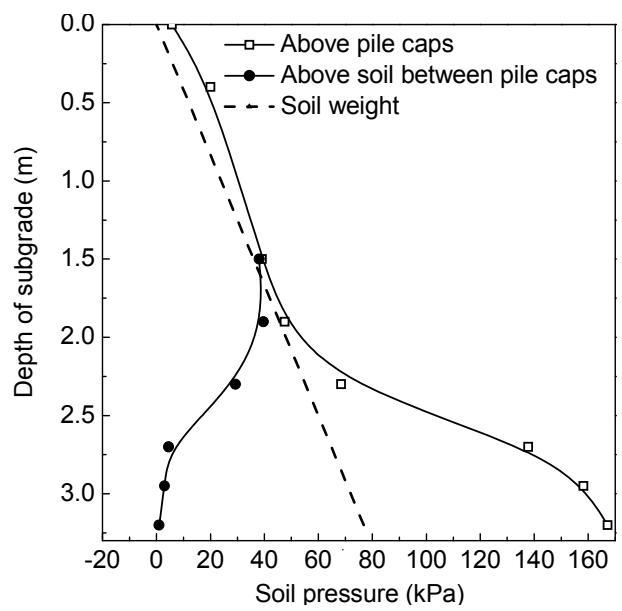

Fig. 1 Static soil pressure in the subgrade (Chen et al., 2014c)

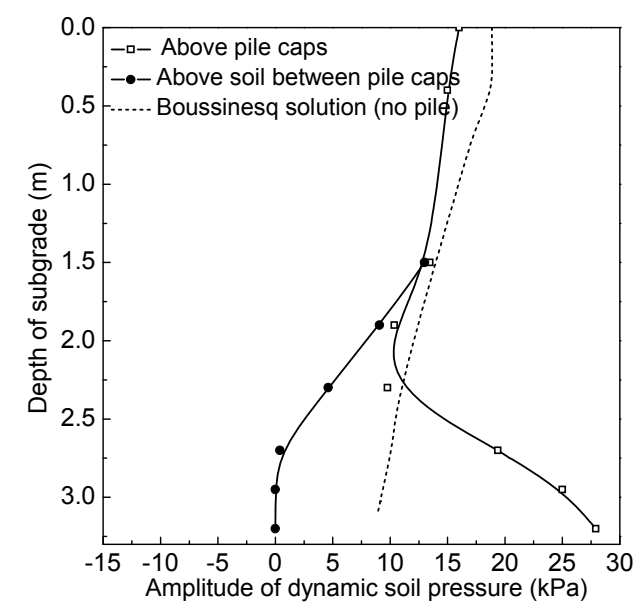

Fig. 2 Dynamic soil pressure in the subgrade (Chen et al., 2014c)

\section{Post-construction settlement of the track-subgrade}

The post-construction settlement of the track consists of the consolidation settlement of foundation soils, accumulative settlement of the subgrade under train loading, and the accumulative settlement of foundation soils (or piles) under train loading. Generally, the post-construction settlement of the subgrade and foundation under static load belongs to a traditional soil mechanics problem. The postconstruction settlement of piled embankments for highways are rarely considered due to the limited total settlement of soil improved with piles. But the post-construction settlement of a piled embankment for high-speed railways becomes important due to the 
strict demands of the settlement. Zhou et al. (2012) developed a semi-solution for solving the consolidation of a piled embankment in soft ground. Puppala and Chittoori (2012) evaluated the effectiveness of deep soil mixing (DSM) columns for stabilizing soils in arresting the distress posed to the pavements. Accumulative settlement of the subgrade under train loadings is a hot research topic. The commonly used research methods are a full-scale triaxial test (Suiker et al., 2005; Ishikawa et al., 2011; Mishra et al., 2013), full-scale model tests (Chen et al., 2014a; 2014b; $2014 \mathrm{c}$ ), and discrete element method (Huang and Chrismer, 2013). It shows that these are three types of the plastic strain development model: plastic shakedown, plastic creep, and incremental collapse (Werkmeister et al., 2005). The development model of plastic strain depends on the ratio between the dynamic stress and initial confining pressure. The greater the ratio is, the more likely the soil will fail. Experimental studies have taken the stress level, number of cycles, particle size distribution, and degree of compaction into consideration.

Although some approaches have been developed to calculate the accumulative settlement, the accuracy of those approaches is low. This is mainly due to the very small accumulative settlement and the uncertainties of the soil parameters. Hence, it is better to propose some threshold values related to the dynamic soil stress to control the development of the accumulative settlement. Further studies should focus on the influence factors on the threshold values, such as saturation, compaction coefficient, gradation, etc. Discrete element method (DEM) and computer tomography (CT) are two useful measures to study the behavior of the subgrade. With the use of pile supported low embankment in soft soil area, pile settlement in the dynamic and static load combinations has become an important part of subgrade settlement. Currently research in this area is not sufficient, high-speed rail design specification shave no clear rules and calculation methods.

\section{Long-term serviceability of subgrade}

During the service life of high-speed railways, the track-subgrade will suffer drying-wetting cycles, dynamic stress cycles and temperature cycles. For example, the variation of temperature in north China will be $60{ }^{\circ} \mathrm{C}$. Nurmikolu (2012) thought it was crucial to understand and take into account the frost action mechanism in cold climate, especially where seasonal frost occurs. The water content in the subgrade will also change greatly from the optimum water content during the construction to the saturation status during the wet season. The change of the water content in the subgrade has a significant impact on the subgrade settlement (Fig. 3, Chen et al., 2014a). Future research tendencies will concentrate on the following aspects: (1) the soil-water characteristic curve and permeability of coarse grained subgrades; (2) the water movement in the subgrade under heavy rainfall. Then, the engineering parameters of the high-speed railway subgrade will be proposed, and advice about fine particles content, grading, and structural design will also be given.

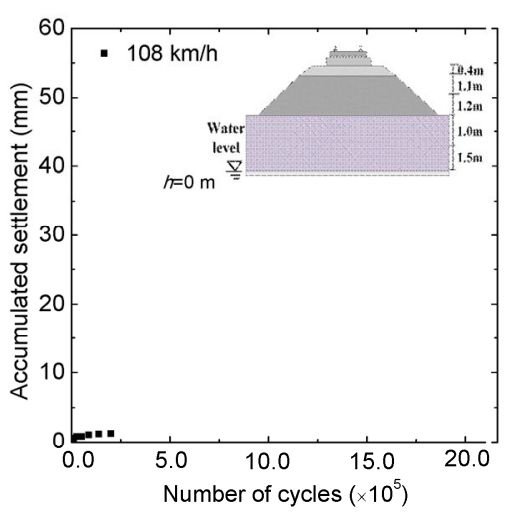

(a)

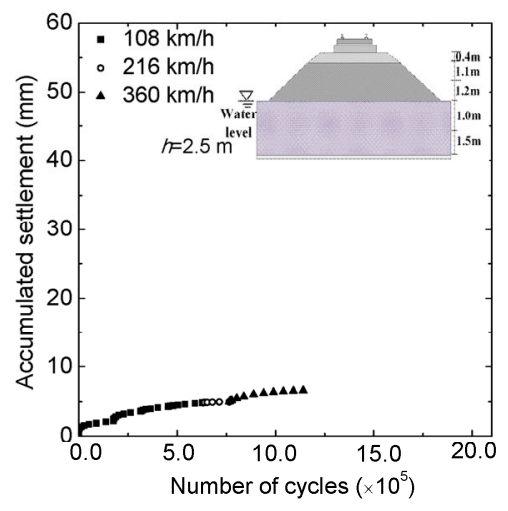

(b)

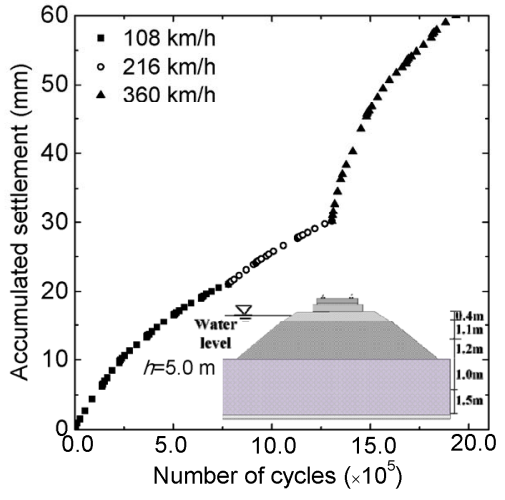

(c)

Fig. 3 Accumulative subgrade settlement under different water levels (Chen et al., 2014a): (a) water level is at the bottom of the foundation; (b) water level is at the top of the foundation; (c) water level is at the top of the subgrade 


\section{Summary}

The high-speed train makes strict demands on the long-term performance of the track-subgrade. The key scientific point of research on the performance of high-speed railway subgrade is the mechanical and hydraulic properties of the subgrade under the coupling of dynamic cycles, dry-wet cycles, and temperature cycles. Much further research work should be done for the maintenance of existing high-speed railways and the new construction of high-speed railways.

\section{References}

Bian, X.C., Chen, Y.M., Hu, T., 2008. Numerical simulation of high-speed train induced ground vibrations using 2.5D finite element approach. Science in China Series G: Physics, Mechanics and Astronomy, 51(6):632-650. [doi:10.1007/s11433-008-0060-3]

Chen, R.P., Ren, Y., Chen, Y.M., 2011. Experimental investigation on single stiff pile subjected long-term axial cyclic loading. Chinese Journal of Geotechnical Engineering, 33(12):1926-1933 (in Chinese).

Chen, R.P., Zhao, X., Wang, Z.Z., et al., 2013. Experimental study on dynamic load magnification factor for ballastless track-subgrade of high-speed railway. Journal of Rock Mechanics and Geotechnical Engineering, 5(4):306-311. [doi:10.1016/j.jrmge.2013.04.004]

Chen, R.P., Chen, J.M., Zhao, X., et al., 2014a. Accumulative settlement of track subgrade in high-speed railway under varying water levels. International Journal of Rail Transportation, 2(4):205-220. [doi:10.1080/23248378. 2014.959083]

Chen, R.P., Zhao, X., Jiang, H.G., et al., 2014b. Model test on deformation characteristics of slab track-subgrade under changes of water level. Journal of the China Railway Society, 36(3):87-93 (in Chinese).

Chen, R.P., Wang, Y.W., Chen, J.M., et al., 2014c. Experimental study on soil arching effect in pile-supported reinforced embankment under train moving loads with larger cycle number. Journal of the China Railway Society, in press (in Chinese).

MRC (Ministry of Railways of China), 2009. Chinese Code for Design of High Speed Railway TB 10621, MRC (in Chinese).

Cui, Y.J., Lamas-Lopez, F., Trinh, V.N., et al., 2014. Investigation of interlayer soil behavior by field monitoring. Transportation Geotechnics, 1(3):91-105. [doi:10.1016/j. trgeo.2014.04.002]

German Railway Standard Rail 836, 2008. Erdbauwerkeplanen, bauen und instandhalten (in German).

Hall, L., 2003. Simulations and analyses of train-induced ground vibrations in finite element models. Soil Dynamics and Earthquake Engineering, 23(5):403-413. [doi:10. 1016/S0267-7261(02)00209-9]

Huang, H., Chrismer, S., 2013. Discrete element modeling of ballast settlement under trains moving at "Critical Speeds". Construction and Building Materials, 38:9941000. [doi:10.1016/j.conbuildmat.2012.09.007]
Ishikawa, T., Sekine, E., Miura, S., 2011. Cyclic deformation of granular material subjected to moving-wheel loads. Canadian Geotechnical Journal, 48(5):691-703. [doi:10. 1139/t10-099]

Metrikine, A.V., 2004. Steady state response of an infinite string on a non-linear visco-elastic foundation to moving point loads. Journal of Sound and Vibration, 272(3-5): 1033-1046. [doi:10.1016/j.jsv.2003.04.001]

Mishra, D., Tutumluer, E., Stark, T.D., et al., 2012. Investigation of differential movement at railroad bridge approaches through geotechnical instrumentation. Journal of Zhejiang University-SCIENCE A (Applied Physics \& Engineering), 13(11):814-824. [doi:10.1631/jzus. A12ISGT7]

Mishra, D., Kazmee, H., Tutumluer, E., et al., 2013. Characterization of railroad ballast behavior under repeated loading. Transportation Research Record: Journal of the Transportation Research Board, 2374(1):169-179. [doi:10.3141/2374-20]

Nurmikolu, A., 2012. Key aspects on the behaviour of the ballast and substructure of a modern railway track: research-based practical observations in Finland. Journal of Zhejiang University-SCIENCE A (Applied Physics \& Engineering), 13(11):825-835. [doi:10.1631/jzus. A12ISGT1]

Puppala, A.J., Chittoori, B.C., 2012. Transportation infrastructure settlement and heave distress: challenges and solutions. Journal of Zhejiang University-SCIENCE A (Applied Physics \& Engineering), 13(11):850-857. [doi:10.1631/jzus.A12ISGT9]

Suiker, A.S.J., Selig, E.T., Frenkel, R., 2005. Static and cyclic triaxial testing of ballast and sub-ballast. Journal of Geotechnical and Geoenvironmental Engineering ASCE, 131(6):771-782. [doi:10.1061/(ASCE)1090-0241(2005) $131: 6(771)]$

Verbraken, H., Lombaert, G., Degrande, G., 2012. Experimental and numerical prediction of railway induced vibration. Journal of Zhejiang University-SCIENCE A (Applied Physics \& Engineering), 13(11):802-813. [doi:10.1631/jzus.A12ISGT8]

Werkmeister, S., Dawson, A.R., Wellner, F., 2005. Permanent deformation behavior of granular materials. Road Materials and Pavement Design, 6(1):31-51. [doi:10.1080/ 14680629.2005.9689998]

Zhai, W.M., Wang, K.Y., Cai, C.B., 2009. Fundamentals of vehicle-track coupled dynamics. Vehicle System Dynamics, 47(11):1349-1376. [doi:10.1080/004231108026 21561]

Zhai, W.M., Xia, H., Cai, C.B., et al., 2013a. High-speed train-track-bridge dynamic interactions-Part I: theoretical model and numerical simulation. International Journal of Rail Transportation, 1(1-2):3-24. [doi:10.1080/ 23248378.2013.791498]

Zhai, W.M., Xia, H., Cai, C.B., et al., 2013b. High-speed train-track-bridge dynamic interactions-Part II: experimental validation and engineering application. International Journal of Rail Transportation, 1(1-2):25-41. [doi:10.1080/23248378.2013.791497]

Zhou, W.H., Chen, R.P., Zhao, L.S., et al., 2012. A semianalytical method for the analysis of pile-supported embankments. Journal of Zhejiang University-SCIENCE A (Applied Physics \& Engineering), 13(11):888-894. [doi:10.1631/jzus.A12ISGT4] 


\section{中文稣要:}

本文题目: 高铁路基近期研究

Recent research on the track-subgrade of high-speed railways

本文概要: 随着高速铁路的快速发展, 高铁路基的研究成为一大热点。目前大量的研究工作集中在高铁路

基动力响应、工后沉降和长期服役性能。这些工作促进了对高铁路基一般规律的了解, 但距准 确评价路基在百年服役过程中经受干湿循环、温度变化与动荷载耦合作用下服役性能的改变尚 远。本文总结了高铁路基近期的研究成果，并提出了未来的研究方向。

关键词组：高铁路基；动力响应；工后沉降；长期服役性能

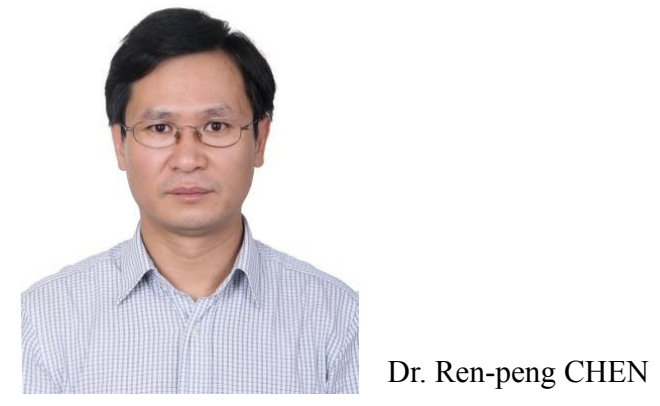

\section{Introducing editorial board member:}

Dr. Ren-peng CHEN is a new editorial board member of Journal of Zhejiang University-SCIENCE A (Applied Physics \& Engineering) in 2014. He is the Qiushi Special-term Professor of Zhejiang University, and the associate director of the Geotechnical Engineering Institute of Zhejiang University, China. He obtained his Master's and PhD degrees in Civil Engineering from Zhejiang University in 1997 and 2001, respectively.
Dr. CHEN's areas of research include soil improvement, road and railway engineering, and pile foundation. His research was supported by more than ten research grants, including the National Natural Science Foundation of China (NSFC) for Distinguished Young Scholars, and High-speed Railway Joint Fund of the State Key Program of NSFC. He has published more than 80 peer-reviewed journal papers and 30 conference papers, and has had ten patents in China approved. Due to his shining achievements in the related field, he received the China Youth Science and Technology Award (for 200 persons every two years in China) in 2011, and was selected for the National Youth Talents for Innovation of Science and Technology in 2013.

Currently, Dr. CHEN serves as the member of TC307 and ATC6 of the International Society for Soil Mechanics and Geotechnical Engineering (ISSMGE), the vice director of the Soft Soil Engineering Committee of the Chinese Institution of Soil Mechanics and Geotechnical Engineering (CISMGE), the vice director of the Strength Theory of Soil and Constitutive Model Committee of CISMGE, and an editorial board member of Rock and Soil Mechanics. 